\title{
Effects of An Acute Exercise Up to Anaerobic Threshold on Serum Anabolic and Catabolic Factors in Trained and Sedentary Young Males
}

\author{
Antrene ve Sedanter Genç Erkeklerde Anaerobik Eşiğe Kadar Yapılan Akut Egzersizin Serum Anabolik ve \\ Katabolik Faktörlerine Etkileri
}

\section{Zeynep Tuna ${ }^{1}$, Nevin Atalay Güzel ${ }^{1}$, Arzu L.Aral ${ }^{2}$, Şehri Elbeg ${ }^{3}$, Çiğdem Özer ${ }^{4}$, Gamze Erikoglu ${ }^{4}$, Ayșegül Atak ${ }^{2}$} Lamia Pınar ${ }^{5}$

\footnotetext{
${ }^{1}$ Gazi University, Faculty of Health Sciences, Physiotherapy and Rehabilitation Department, Besevler, Ankara, Turkey

${ }^{2}$ Gazi University Faculty of Medicine, Department of Immunology, Besevler, Ankara, Turkey

${ }^{3}$ Gazi University Faculty of Medicine, Department of Biochemistry, Besevler, Ankara, Turkey

${ }^{4}$ Gazi University School of Physical Education and Sports, Besevler, Ankara, Turkey

${ }^{5}$ Gazi University, Faculty of Medicine, Department of Physiology, Besevler, Ankara, Turkey
}

\section{ABSTRACT}

Objective: The aim of the present study was to evaluate the effects of aerobic running exercise up to anaerobic threshold in trained $(T)$ and sedentary $(\mathrm{S})$ young males.

Methods: The catabolic factors such as interleukin-6 (IL-6), oxidants and cortisol and the anabolic factors such as testosterone, growth hormone (GH) and insulin-like growth factor (IGF-I) were evaluated in blood serum of subjects.

Results: It was found that running up to anaerobic threshold led to a significant increase in oxidants but not IL-6 in both groups. Indeed, oxidants returned to basal levels in $24 \mathrm{~h}$ in the T group. Cortisol decreased even below the basal levels $24 \mathrm{~h}$ after exercise in both groups. Anabolic hormones increased in both groups especially in the trained subjects after exercise. Conclusion Trained young people showed faster anabolic and catabolic adaptation to aerobic exercise comparing to age-matched sedentaries.

Key words: Aerobic exercise, oxidants, antioxidants, testosterone, cortisol
ÖZET

Amaç: Bu çalışmanın amacı antrene ve sedanter genç erkeklerde anaerobik eşiğe kadar yapılan aerobik egzersizin etkilerini araştırmaktır.

Yöntemler: Katılımcıların kan örneklerinde İnterlökin-6 (IL-6), oksidanlar ve kortizol gibi katabolik faktörler ile testosterone, büyüme hormonu ve insülin benzeri büyüme faktörü-1 gibi anabolik faktörlerin düzeyleri ölçülmüştür. Bulgular: Anaerobik eşiğe kadar yapılan koşu egzersizinin her iki grupta da oksidanları arttırdığı fakat IL-6 düzeylerini etkilemediği görülmüştür. Ayrıca oksidanlar antrene grupta 24 saat içinde bazal düzeylere inmiştir. Kortizol miktarı egzersizden 24 saat sonra her iki grupta da bazal düzeyin dahi altına düşmüştür. Anabolik hormonlar ise, özellikle antrene grupta olmak üzere her iki grupta da egzersizden sonra artış göstermiştir.

Sonuç: Antrene gençler egzersize, aynı yaş grubundaki sedanterlere göre daha hızı anabolik ve katabolik adaptasyon göstermektedirler.

Anahtar Sözcükler: Aerobik egzersiz, oksidanlar, antiksidanlar, testosteron, kortizol 


\section{INTRODUCTION}

The field of exercise science extends to a very large portion of our daily life, ranging from elite sports performance to the maintenance of health and the management of diseases and disability (1). In bold outline, exercise can be divided into two categories: Aerobic or cardiorespiratory exercise involves large muscle groups and effects prominently the cardiovascular and respiratory systems increasing their capacity and improving blood lipid profile $(1,2)$. Anabolic or resistance exercise involves performing sets of repeated movements against a resistance during which neuromuscular fatigue occurs within a few repetition (1). The border between aerobic and anaerobic exercises is anaerobic (lactate) threshold. There are several methods used to determine an athlete's lactate or anaerobic threshold. The most accurate and reliable method is through the direct testing of blood samples during a graded exercise test. Lactate threshold is the point during exercise of increasing intensity at which blood lactate begins to accumulate above resting levels $(>0,8-1 \mathrm{mmol} / \mathrm{L})$, where lactate clearance is no longer able to keep up with lactate production.

During low intensity exercise, blood lactate remains at or near resting levels. As exercise intensity increases there comes a breaking point where blood lactate levels rise sharply. It is suggested that sharp rise shows a significant shift from predominantly aerobic metabolism to predominantly anaerobic energy production. It is also called lactate threshold, anaerobic threshold, onset of blood lactate accumulation or maximal lactate steady state. The anaerobic threshold is the slope of the increase in carbondioxide output with respect to oxygen uptake during exercise (3). Most prominent effects of anaerobic exercises are on the neural and muscular systems but marked changes also occur to the endocrine and skeletal systems (1).

Exercise training efficiency depends on the intensity, duration and frequency of training (4). For last 20 years, it has been recognized that skeletal muscle cells release some cytokines in response to several kinds of exercise. The mostly produced cytokine by contracting muscle cells is interleukin 6 (IL-6) and called 'myokine' (5). IL-6 levels rise, especially under inflammatory conditions, leading to stimulation of the anti-inflammatory pathways (6). After a destructive effect of a strenuous exercise, IL-6 activates the neutrophils for phagocytosis and triggers the oxidants, but concomitantly stimulates the antioxidant process (7). IL-6 also stimulates catabolic factors like cortisol, interleukin-1 receptor antagonist (IL-1ra) and anti-inflammatory cytokines like IL-10 $(8,9)$.

Cortisol as a stress hormone has a catabolic (muscle breakdown) effect on tissue and is associated with a decrease in anabolic hormones like insulinlike growth factor (IGF-1) and growth hormone (GH) (10). Cortisol is a hormone produced by the adrenal cortex and known as the regulator of immune response. A prominent role of acute cortisol response is to meet the greater metabolic demands of resistance exercise.

Single heavy resistance exercise leads to acute increases in serum anabolic hormone concentrations (i.e., testosterone, GH and (GF-I). The magnitudes of acute neuromuscular and hormonal responses are influenced by exercise variables such as the volume and the intensity of exercise (1). According to the literature it has been known that cortisol and testosterone serum values are altered due to exercise habits. Continuous training programs increase the testosterone levels and decrease the cortisol. Thus, reducing levels of cortisol is ideal for an athlete to achieve tissue growth and positive adaptations to exercise training (10).

Exercise is a robust physiological stimulator of the pituitary secretion of $\mathrm{GH}$ and within approximately $15 \mathrm{~min}$ after the onset of exercise, plasma GH starts to increase. GH and its primary mediator -IGF-1- play a critical role in formation, maintenance and regeneration of skeletal muscles. Studies have shown that there are positive correlations between circulating IGF-1 levels and $\mathrm{GH}$ secretion and the indices of fitness (11). The effects of $\mathrm{GH}$ in promoting body growth are IGF-1 dependent, but IGF-1 independent functions are beginning to be elucidated (12).

In the literature, the most prominent catabolic and anabolic effects of exercise have been shown for the intense and long-lasting exercises. However, in daily life, majority of population rarely contributes to such intense and long lasting exercises. Moreover, in public health organizations, the established recommendation that regular physical exercise of at least 30minutes for health has recently changed to the idea that shorter durations like 10 minute-periods could also be beneficial. It has been claimed that even such a short duration exerts metabolic shifts in the organism (13). However, the literature on the effects of such a short exercise period on immune, oxidative and metabolic states is very poor.

For those reasons, in this study, we investigated the effects of acute aerobic running exercise up to anaerobic threshold on catabolic and anabolic processes. And these effects were compared between the long term trained soccer players and age-matched sedentary subjects. In those processes the inflammatory cytokines IL-6, anti-inflammatory cytokines IL-10; oxidants and antioxidants, catabolic hormone cortisol and anabolic hormones testosterone, GH and IGF-I were assessed in the trained (T) and sedentary (S) young men before, immediately after and 24 hours after the aerobic exercise. Thereby, results were compared between the outcomes of sedentary or physically active lifestyles.

\section{MATERIAL and METHODS}

\section{Participants and Study Design}

Sixteen young male soccer players and 10 age-matched sedentary students voluntarily participated in the study. The study design was approved ethically by Ankara Clinical Research Ethics Committee (03.12.2009, no: 45). Each subject was informed about the study and all gave their written informed consent to participate. A physician, a physiotherapist and a doctoral student in the sports academy supervised all the participants during the test. None of the testing subjects were taking any medication that could affect the physical performance. Inclusion criterion was exercising 3 times per week at least for last 2 years for the trained group. For sedentary, the criterion was the absence of regular exercise 3 times per week for more than 15 minutes for the past 2 years (14).

During the experiment three blood samples were obtained from each subject. Blood samples were drawn in the morning after 12 hours of fasting so that basal serum hormone concentrations could be determined.

\section{Experimental procedure}

Both groups performed 'multi stage shuttle run test' (15) following set up and calibration of equipments a day before the test. Exercise test and all blood samplings were completed between 8.00 and 10.00 a.m. in the morning.

Age, height and body weight of participants were recorded and exercise protocol was explained in detail before the test. The participant started running on a treadmill at $8 \mathrm{~km} / \mathrm{h}$ speed for 3 minutes and continued at a 10 $\mathrm{km} / \mathrm{h}$ speed for the next 3 minutes. From that point, the speed increased 1 $\mathrm{km} / \mathrm{h}$ at the end of each 3-minute period. At each pause between 3-minute running periods blood samples were obtained from earlobe and the lactate level was measured immediately by lactate analyzer (YSI 1500 Sport, Yellow Sprint Ohio, USA). As long as the lactate level was under anaerobic threshold ( $<4 \mathrm{mmol} / \mathrm{L}$ ) (16), the participant went on with the next step. For each participant the test finished when he reached or exceeded $4 \mathrm{mmol} / \mathrm{L}$ anaerobic lactate threshold for the first time.

Blood samples were obtained before the test (BT), immediately after the test (AT) and 24 hours after the test (24hAT) from antecubital vein. Samples were centrifuged at $3500 \mathrm{rpm}$ at $4^{\circ} \mathrm{C}$ for 15 minutes and stored at $-80^{\circ} \mathrm{C}$ until analysis. All analyses were performed in the research laboratories of Gazi University Faculty of Medicine.

\section{Cytokine and Hormone Assays}

IL-6, IL-10 and cortisol levels were measured using commercial Enzyme Linked Immunosorbent Assay (ELISA) kits in Immunology Research Laboratory according to the manufacturer's instructions (Human IL-6 ELISA, Bender MedSystems GmbH, Austria; Human IL-10 ELISA, Bender MedSystems GmbH, Austria; Cortisol ELISA, DRG Instruments, Germany). Analytical sensitivities were $0.98 \mathrm{pg} / \mathrm{ml}$ for IL-6, and $1 \mathrm{pg} / \mathrm{ml}$ for IL-10. Optic densities (OD) developed after the study have been measured using a 450 $\mathrm{nm}$ filter with an automathized ELISA reader spectrophotometrically.

Serum free testosterone and IGF-1 levels were measured using commercial Radioimmunoassay (RIA) kits (Free Testo-RIA-CT, IGF-I-RIA-CT; DIASource Immunoassays S.A., Belgium) and $\mathrm{GH}$ levels were measured using an immunoradiometric assay (hGH-IRMA, DIASource Immunoassays S.A., Belgium) in Biochemistry Laboratory according to the manufacturer's instructions. Analytical sensitivities were $0.13 \mathrm{pg} / \mathrm{ml}, 3.4 \mathrm{ng} / \mathrm{ml}$ and 0.04 $\mu \mathrm{IU} / \mathrm{ml}$, respectively.

\section{Malondialdehyde (MDA) and Total Sulfhydryl Groups (RSH) Assays}

MDA and RSH levels were measured in the Physiology Laboratory. MDA, which is a predictor of lipid peroxidation, was measured by TBARS formation in the serum. (17). Antioxidant capacity was evaluated by measuring total sulfhydrile groups (RSH) spectrophotometrically (17)

\section{Statistical Analysis}

Statistical analyses were performed by SPSS Windows 16.0. Friedman test was used to evaluate the effect of time (pre-, post-exercise and 24 hours later) on parameters within groups. If analyses revealed a significant difference, Wilcoxon test was used to locate specific differences. 
Also, Mann Whitney $U$ test was used to compare groups for values at the same time point. Cytokine levels were calculated using Microstat software. For all analysis, a value of $p<0.05$ was considered statistically significant.

\section{RESULTS}

Age, height, weight and body mass index (BMI) of both groups are shown in Table 1. The mean duration of exercise test was 10.9 minutes.

Table 1 :Age, height, weight and body mass index (BMI) comparison of both groups ( $p>0.05$ ) (Data have been presented as 'mean \pm standard error')

\begin{tabular}{|c|c|c|c|c|}
\hline & Age (years) & Height $(\mathrm{cm})$ & $\begin{array}{l}\text { Body Weight } \\
\text { (kg) }\end{array}$ & BMI $\left(\mathrm{kg} / \mathrm{m}^{2}\right)$ \\
\hline $\begin{array}{l}\text { Trained } \\
\text { (N:16) }\end{array}$ & $18.75 \pm 1.25$ & $179.12 \pm 14.12$ & $73.25 \pm 12.25$ & $22.86 \pm 3.09$ \\
\hline $\begin{array}{l}\text { Sedentary } \\
\text { (N:10) }\end{array}$ & $20.60 \pm 3.40$ & $172 \pm 7$ & $71.6 \pm 19.4$ & $24.10 \pm 4.04$ \\
\hline
\end{tabular}

\section{Hormones}

\section{Testosterone}

Baseline levels of testosterone were different slightly but insignificantly $(p>0.05)$. In trained $(T)$ group serum testosterone levels increased \%25 as compared to the baseline $(p<0.05)$. In sedantery (S) group serum testosterone concentration increased $\% 16.5$ but the difference was insignificant ( $p>0.05)$. Higher serum testosterone levels of both groups were maintained as compared to basal levels 24 hours later; but, the differences were not statistically significant ( $p>0.005$ ) (Table 2 ).

\section{Testosterone/Cortisol Ratio}

Testosterone/cortisol (tes/cor) ratio after running test was found higher in the $T$ group than the $S$ group $(p<0.05)$. In $T$ group, tes/cor ratio increased significantly with the exercise as compared to baseline and was maintained at this high level even 24 hours later $(p<0.05)$. The slight increase in the tes/cor ratio in the $S$ group after the test was not statistically significant (Figure 1).

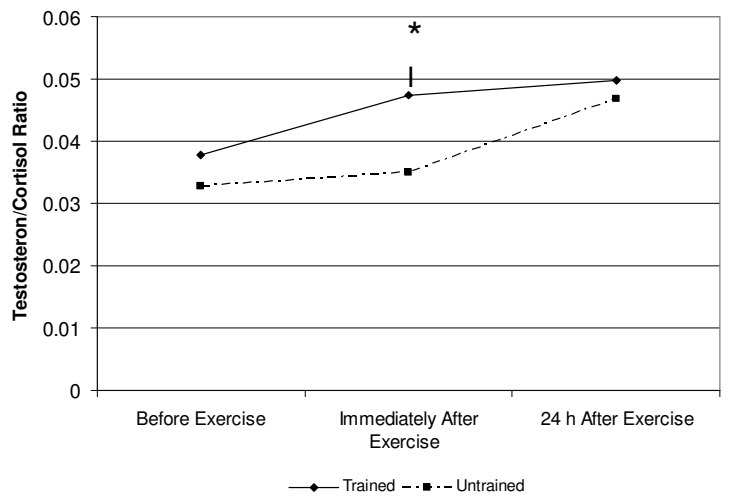

Figure 1: Testosteron/Cortisol ratio of both groups before, immediately after and 24 hours later exercise $\left({ }^{*} p<0.05\right)$

Table 2: Malondialdehyde (MDA), total sulfhydrile groups (RSH) and hormone levels in trained and untrained groups. ${ }^{*} p<0.05$ : comparison of levels before and immediately after exercise; ${ }^{* *} p<0,05$ comparison of levels before and 24 hours later exercise; $¥ p<0.05$ : comparison of levels immediately after and 24 hours later exercise

\begin{tabular}{lllllll}
\hline & \multicolumn{3}{l}{ Sedentary Group } & \multicolumn{3}{l}{ Trained Group } \\
& $\begin{array}{l}\text { Before } \\
\text { exercise }\end{array}$ & $\begin{array}{l}\text { Immediately } \\
\text { after exercise }\end{array}$ & $\begin{array}{l}\text { 24h after } \\
\text { exercise }\end{array}$ & $\begin{array}{l}\text { Before } \\
\text { exercise }\end{array}$ & $\begin{array}{l}\text { Immediately } \\
\text { after exercise }\end{array}$ & $\begin{array}{l}\text { 24h after } \\
\text { exercise }\end{array}$ \\
\hline $\begin{array}{l}\text { MDA } \\
\text { (nmol/ml) }\end{array}$ & $4.92 \pm 0.20$ & $6.3 \pm 0.48$ & $6.4 \pm 1.6$ & $5.01 \pm 0.22^{*}$ & $6.34 \pm 0.33^{*}$ & $5.37 \pm 0.30$ \\
RSH (nmol/ml) & $476.90 \pm 30.00^{*}$ & $376.02 \pm 30.28^{*}$ & $314.83 \pm 31.31$ & $342.26 \pm 15.88^{*}$ & $255.41 \pm 22.58^{*}$ & $327.44 \pm 19.35$ \\
$\begin{array}{l}\text { Cortisol } \\
\text { (ng/ml) }\end{array}$ & $441,00 \pm 19,4$ & $465,75 \pm 7,6^{*}$ & $394,33 \pm 25,2^{*}$ & $447,11 \pm 10,8^{* *}$ & $446,02 \pm 17$ & $401,75 \pm 13,1^{* *}$ \\
$\begin{array}{l}\text { Testosteron } \\
\text { (pg/ml) }\end{array}$ & $14,62 \pm 1,74$ & $16,34 \pm 1,73$ & $17,50 \pm 2,00$ & $16,28 \pm 1,03^{*}$ & $20,26 \pm 1,40^{*}$ & $19,70 \pm 1,26$ \\
$\begin{array}{l}\text { Growth } \\
\text { Hormon(IU/ml) } \\
\text { IGF-1 (ng/ml) }\end{array}$ & $0,40 \pm 0,05^{*}$ & $4,52 \pm 0,98^{*}$ & $3,60 \pm 2,21$ & $2,86 \pm 1,07^{*}$ & $23,12 \pm 4,08^{*}$ & $2,62 \pm 1,28$ \\
\hline
\end{tabular}

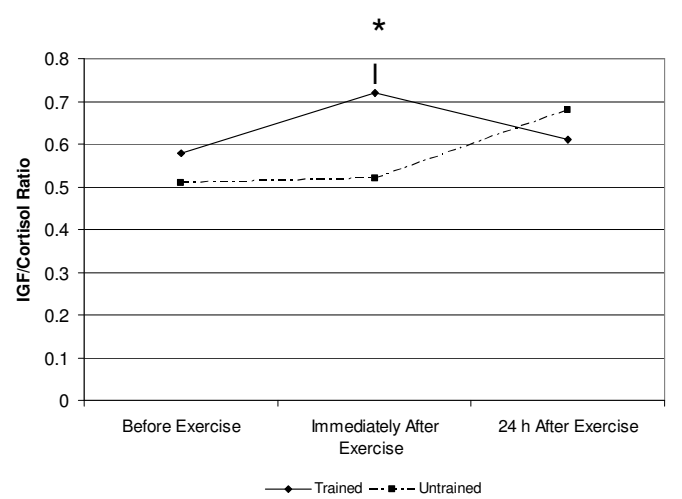

Figure 2: IGF/Cortisol ratio of both groups before, immediately after and 24 hourc later exercice ${ }^{*} \mathrm{n}<0,05$

\section{GH}

Baseline levels of $\mathrm{GH}$ were high in $\mathrm{T}$ group as compared with the $\mathrm{S}$ group $(p<0.05)$. T group showed a dramatic increase in serum $\mathrm{GH}$ concentrations after the test as compared to the baseline $(p<0.0001)$ whereas it dropped to the baseline $24 \mathrm{~h}$ after the test with an insignificant change $(p>0.05)$. In $\mathrm{S}$ group, serum $\mathrm{GH}$ concentrations markedly increased with the exercise $(\mathrm{p}<0.0001)$ and remained high $24 \mathrm{~h}$ after test with a significant difference as compared to the baseline $(p<0.05)$ (Table 2$)$.

\section{IGF-I}

Baseline serum IGF-1 levels of both groups were similar $(p>0.05)$. In T group, post-exercise serum IGF-1 concentrations were higher as compared to the pre-exercise levels $(p<0.05)$ and $24 \mathrm{~h}$ after the test, dropped below the baseline $(p<0.05)$. In $\mathrm{S}$ group, serum IGF-1 concentrations increased slightly but insignificantly after test and were maintained at this level as compared to baseline ( $p>0.05$ ) (Table 2$)$

\section{Cortisol}

Baseline levels of serum cortisol were similar between groups ( $p>0.05)$. In the T group, serum cortisol levels did not change with the test $(p>0.05)$. In the $S$ group, post-exercise serum cortisol levels were found to increase slightly but this increase was insignificant $(p>0.05)$. Surprisingly, $24 \mathrm{~h}$ after the test, serum cortisol levels decreased below the baseline levels significantly $(p<0.05)$ (Table 2$)$.

\section{IGF-I/Cortisol Ratio}

IGF-1/cortisol (IGF-1/cor) ratio after exercise was found to be higher in the $\mathrm{T}$ group as compared to the $\mathrm{S}$ group but the difference was not significant. In the T group, IGF-1/cor ratio increased with exercise as compared to baseline $(p<0.05)$. Twenty-four $h$ after the running test, IGF$1 /$ cor ratio returned to baseline in the $T$ group, but increased in the $S$ group, however the differences were not significant ( $p>0.05$ ) (Figure 2).

\section{Cytokines}

IL-6 and IL-10 levels were all under detectable values in spite of high sensitivity of ELISA kits $(0.98 \mathrm{pg} / \mathrm{mL}$ for IL- 6 and $1 \mathrm{pg} / \mathrm{mL}$ for IL-10). All participants had cytokine levels over blank $(0 \mathrm{pg} / \mathrm{mL})$ but under minimal detectable point.

\section{MDA and RSH}

MDA levels increased after the acute exercise bout $(5.01 \mathrm{nmol} / \mathrm{mL} ; 6.34$ $\mathrm{nmol} / \mathrm{mL} ; \mathrm{p}<0.01)$ and decreased to basal levels 24 hours later (5.36 $\mathrm{nmol} / \mathrm{mL}$; $\mathrm{p}<0.05$ ) in the trained group. Also in sedentaries MDA increased with exercise $(4.91 \mathrm{nmol} / \mathrm{mL} ; 6.30 \mathrm{nmol} / \mathrm{mL}$; $<<0.05)$ but remained high 24 hours later $(6.40 \mathrm{nmol} / \mathrm{mL} ; \mathrm{p}>0.05)$. Comparison of two groups showed that MDA levels were higher in sedentaries than the trained group only 24 hours later $(\mathrm{p}<0.05)$ (Table 1$)$.

RSH levels of the trained group decreased after the exercise session (342.26 nmol $/ \mathrm{mL} ; 255.40 \mathrm{nmol} / \mathrm{mL} ; \mathrm{p}<0.01$ ) but returned to basal levels 24 hours later $(327.43 \mathrm{nmol} / \mathrm{mL}$; $\mathrm{p}<0.05)$. 
In sedentaries RSH declined with exercise too ( $p<0.01)$; but, it continued to decrease 24 hours later (314.82 nmol/mL; p>0.05) (Table 1).

\section{DISCUSSION}

Exercise training efficiency depends on the intensity, volume, duration and frequency of training (4). This study showed that, even a short-duration aerobic exercise of about 10 minutes up to anaerobic threshold exerted different effects on the anabolic and catabolic processes.

Literature review shows that contracting muscles can produce proinflammatory and anti-inflammatory immunomodulators like IL-6 and IL-10 due to the duration and the intensity of the exercise (18). Inflammatory cytokines have direct catabolic effects on skeletal muscle as IL-6 increases muscle protein degradation (19). In our study low exercise intensity up to anaerobic threshold did not produce any immune response neither inflammatory (IL-6) nor anti-inflammatory (IL-10).

The results in the literature regarding the effects of exercise training on cytokines are much less convincing. Some studies have shown exerciseinduced reduction (20) or unchanged levels (21) of serum inflammatory cytokines. Indeed, it is claimed that exercise training may induce local antiinflammatory effects in skeletal muscle that may not be reflected in the systemic circulation (13). In our experiment, running exercise up to the anaerobic threshold took 10.9 minutes on average (data not shown). Much of the test protocols used in the majority of the studies investigating the 'immune response to contraction' is the long lasting exhausting exercises (22). Logarithmic calculations pointed out that exercise should last for at least 1.9 hours for a 10 -fold increase in IL-6 levels (23). However, majority of population rarely contributes to such intense and long lasting exercises. In daily life, submaximal moderate aerobic exercises appear in most public health recommendations $(13,22)$. Therefore, such a short duration submaximal exercise did not exert a systemic effect on the cytokine levels. Indeed, the serum IL- 6 and IL-10 levels in all participants were below the detectable point. Similar to our results, Markovitch et al. (24), showed that there was no change in serum IL- 6 and IL-10 with an acute moderate exercise bout at $\% 50$ of $\max \mathrm{VO}_{2}$ for 30 minutes, either (24).

Nearly all kinds of exercise stimulate the production of free radicals (25). To interpret the probable effects of free radicals on anabolic and catabolic hormones and to build a relationship between them, we assessed serum lipid peroxidation with exercise in all subjects by MDA levels (17). Our exercise model stimulated MDA production in both groups with a recovery 24 hours after test in the trained group. But in sedentaries group such a recovery was not observed.

In normal physiological conditions cellular antioxidant systems defend against oxidant destroy. We found a reduction in RSH with exercise during the test in both groups which shows that contracting muscles take RSH from blood and utilize them against oxidants (26). Twenty-four hours after the test, both reduction of oxidants and the return of anti-oxidants to the normal levels in the E-T group, showed that the trained people are better adapted to the stress of exercise.

In this study basal serum cortisol concentrations were similar in both groups. After the test it increased slightly in the $\mathrm{S}$ group, but didn't increase in the E-T group. Surprisingly, cortisol levels dropped $24 \mathrm{~h}$ after the test both in E-T and S groups. Our results showed that the intensity of exercise up to anaerobic threshold did not cause a stress response. Ahtiainen et al. (1) supposed that the greater acute cortisol response during heavy exercise might be due to the greater metabolic demands which mediate some of the responses via glycolytic and catecholaminergic stimulatory mechanism (1). In our study, the type of exercise was an aerobic exercise; and, it was stopped at the anaerobic threshold. So the muscles did not use the glycolytic metabolism. As it was shown, acute cortisol response occurs when the overall stress of the exercise protocol is very high (27).

Against catabolic factors, we evaluated serum testosterone responses after the running test. Testosterone is an anabolic hormone that exerts a potent effect on skeletal muscle. We saw that serum testosterone level increased significantly after the test in E-T group and it remained high after 24h. However, the slight increase in the $S$ group after the test was insignificant. It is proposed that increased testosterone release is due to a direct (LH-independent) stimulatory effect of lactate on the secretion of testosterone. Therefore, it may be possible that exercise-induced hormone responses are physiologically important for the adaptation process during training. Studies showed that, in particular, changes in the magnitude of exercise-induced testosterone responses during strength training seem to be related to the gains in muscle mass (1).
Testosterone and cortisol are both produced from the same raw materials which mean that the body can produce one or the other at any time. Thus, where cortisol is high, testosterone production is correspondingly low or vice versa. Ratios of anabolic to catabolic hormones (ie.Testosterone/cortisol or IGF-1/cortisol) may be important markers for the detection of beneficial effects on skeletal muscle. Scientists use the free testosterone/cortisol ratio (tes/cor) and IGF-I/cortisol (IGF-I/cor) to evaluate athletes' training state (10). In our study, the free tes/cor and IGF-1/cor ratios were assessed. It was found that basal tes/cor ratio is high in trained subjects as compared to sedentaries; but the difference was not significant probably due to lower number of samples. In the trained group, tes/cor ratio began to increase clearly during the running period and kept on to increase after the running test in a moderate mode until $24 \mathrm{~h}$ later the test. This rise in tes/cor ratio was significant as compared to basal levels and tes/cor levels of $\mathrm{S}$ group. The ratio of tes/cor in $\mathrm{S}$ group increased not during the test but $24 \mathrm{~h}$ later the test. The sharp increase of tes/cor after the test is preserved even $24 \mathrm{~h}$ later in $\mathrm{S}$ group. The literature reports that cortisol and testosterone serum values are altered due to exercise habits. Excessive cortisol suppresses one's immune system and results in a catabolic state by breaking down muscle and storing fat. Continuous training programs increase the testosterone levels and decrease cortisol in turn. (10). In our study, the fact that tes/cor ratio was high in trained group just after the test and remained high throughout the recovery period for $24 \mathrm{~h}$ indicates that the anabolic adaptation of this groupto exercise was rather rapid than $S$ group.

Also the IGF-I/cor ratio was higher in the trained group as compared to $S$ group after the exercise. IGF-I/cor ratio returned to basal levels in trained group but not in the $\mathrm{S}$ group $24 \mathrm{~h}$ after the exercise. A study of Vellosa had shown that muscle-specific IGF-1 infusion has a hypertrophic effect in anima models and muscle cell culture system (12). Indeed, low levels of IGF-I were found to contribute to the impairment of muscle structure and mobility (28).

Schwarz et al. (29) measured the circulating levels of GH and IGF-I in response to brief exercise of different intensities. After 10 minutes of lowintensity exercise, IGF-I exceeded the pre-exercise baseline by $7.7 \pm 2.7 \%$. In this study, $\mathrm{GH}$ reached its peak $10 \mathrm{~min}$ after the cessation of high intensity exercise, too. It was concluded that brief exercise leads to small but significant increases in circulating IGF-1, and these responses may be influenced by exercise intensity (29). We found basal GH levels in trained group to be significantly higher as compared to sedentary subjects. The test also led to a significant increase of the $\mathrm{GH}$ in both groups. While it returned to basal levels in the trained group 24 hours after the test, it did notin $S$ group.

\section{CONCLUSION}

This study showed that a short duration aerobic exercise up to anaerobic threshold did not exert any catabolic effects in the exercise-trained and sedentary subjects. The increase in serum oxidants and cortisol levels after the exercise returned to the baseline faster in the trained group. The increase in the anabolic hormones like testosterone, GH and IGF-I with a more distinctive increase in the trained subjects may indicate that the anabolic adaptation to exercise was faster in trained young males.

It was also showed that a brief aerobic exercise up to anaerobic threshold had no effect on systemic cytokine response. It did not alter the stress hormone-cortisol; but did stimulate the anabolic hormones; testosterone, GH and IGF-I levels especially in the trained group and slightly in sedentary subjects. Furthermore, the recovery of the systemic catabolic effects of the oxidants and cortisol after the test was more rapid in the trained subjects as compared to sedentary subjects. These findings reveal that a brief submaximal running exercise up to anaerobic threshold would not affect immune system response through myokines, but would increase the anabolic homones like GH, IGF-1 and testosterone, especially in the trained people.

\section{Conflict of Interest}

No conflict of interest was declared by the authors.

\section{REFERENCES}

1. Ahtiainen JP, Pakarinen A, Kraemer WJ, Hakkinen K. Acute Hormonal Responses to Heavy Resistance Exercise in Strength Athletes versus Nonathletes. Can J Apply Physiol 2004; 29: $527-$ 43.

2. Narin SO, Pinar L, Erbas D, Ozturk V, Idiman F. The effects of exercise and exercise-releated changes in blood nitric oxide level on migraine headache. Clin Rehab 2003; 17: 624-30. 
3. Tanaka K, Matsaura Y, Kumagai S, Matsuzuka A, Hirakoba K, Asano K. Relationships of anaerobic threshold and onset of blood lactate accumulaton with endurance performance. Eur J Apply Physiol Occup Physiol 1983; 52: 51-6.

4. Meckel Y, Eliahim A, Seraev M, Zaldivar F, Cooper DM, Sagiv M, et al. The effect of a brief sprint interval exercise on growth factors and inflammatory mediators. Strength Cond Res 2009; 23: 225-30.

5. Pedersen BK, Ostrowski $\mathrm{K}$, Rohde $\mathrm{T}$, Bruunsgaard $\mathrm{H}$. The cytokine response to strenuous exercise. Can J Physiol Pharmacol. 1998;76:505-11.

6. Bodell PW, Kodesh E, Haddad F, Zaldivar FP, Cooper DM, Adams GR. (2009) Skeletal muscle growth in young rats is inhibited by chronic exposure to IL- 6 but preserved by concurrent voluntary endurance exercise. J Appl Physiol; 106: 443-53.

7. Niess AM, Sommer M, Schneider M, Angres C, Tschositsch, Golly IC, et al. Physical exercise-induced ekspression of inducible nitric oxide synthase and heme oxygenase-1 in human leukocytes: effects of RRR-alpha-tocopherol supplementation. Antioxid Redox Signal 2000; 2: 113-26.

8. Pedersen BK, Steensberg A, Fischer C, Keller C, Keller P, Plomgaard $\mathrm{P}$, et al. The metabolic role of IL-6 produced during exercise: is IL- 6 an exercise factor? Proceed Nutrition Society 2004; 63: 263-7.

9. Steensberg A, Fischer CP, Keller C, Moller K, Pedersen BK. IL-6 enhances plasma IL-1ra, IL-10, and cortisol in humans. Am J Physiol Endocrinol Metab 2003; 285: 433-7.

10. Hug $M$, Mullis $P E$, Vogt $M$, Ventura $N$, Hoppeler $H$. Training modalities over-reaching and over-training in athletes, including a study of the role of hormones. Best Pract Res Clin Endocrinol Metab. 2003; 17: 191-209.

11. Frystyk J. Exercise and growth hormone-insulin-like growth factor axis. Med Sci Sports Exerc 2010; 42: 58-66.

12. Vellosa CP. Regulation of muscular Mass by Growth Hormone and IGF-1. Br J Pharmacol 2008; 154: 557-68.

13. Haskell WL, Lee IM, Pate RR, Powell KE, Blair SN, Franklin BA, et al. Physical Activity and Public Health: Updated Recommendation for Adults from American College of Sports Medicine and the American Heart Association. Med Sci Sports Exerc 2007; 39: 142334.

14. Arai $\mathrm{MH}$, Duarte AJS, Natale VM. The effects of long-term endurance training on the immune and endocrine systems of elderly men: the role of cytokines and anabolic hormones. Immun Ageing 2006; 3: 9.
15. Léger LA, Mercier D, Gadoury C, Lambert J. The multistage 20 metre shuttle run test for aerobic fitness. J Sports Sci 1988; 6: 93101.

16. Wasserman K, Beaver WL, Whipp B. Mechanism and Patterns of Blood Lactate Increase During Exercise in Men. Med Sci Sports Exerc 1986; 18: 344-52.

17. Kurtel H, Granger DN, Tso P, Grisham MB. Vulnerability of intestinal interstitial fluid to oxidant stress. Am J Physiol Gastrointest Liver Physiol 1992; 263: 573-8.

18. Woods JA, Vieira VJ, Keylock KT. Exercise, inflammation and innate immunity. Immunol Allergy Clin N Am 2009; 29: 381-93.

19. Fujita J, Tsujinaka T, Ebisui $C$, Monden M. Role of interleukin- 6 in skeletal muscle protein breakdown and cathepsin activity in vivo. Eur Surg Res 1996; 28: 361-6.

20. LeMaitre JP, Harris S, Fox KA, Denvir M. Change in circulating cytokines after 2 forms of exercise training in chronic stable heart failure. Am Heart J 2004; 147:100-5.

21. Nicklas BJ, Ambrosius W, Messier SP, Miller GD, Penninx BW, Loeser RF, et al. Diet-induced weight loss, exercise, and chronic inflammation in older obese adults: a randomized controlled clinical trial. Am J Clin Nutr 2004; 79: 544-51.

22. Department of Health and Human Services (DHHS). Centers for Disease Control and Prevention, National Center for Chronic Disease Prevention and Health Promotion. Physical Activity and Health: A Report of Surgeon General. Atlanta GA: DHHS; 1996.

23. Fischer $\mathrm{CP}$. Interleukin- 6 in acute exercise and training: what is the biological relevance? Exerc. Immunol. Rev. 2006; 12: 6-33.

24. Markovitch D, Tyrrell RM, Thompson D. Acute moderate-intensity exercise in middle-aged men has neither an anti- nor proinflammatory effect. J Appl Physiol 2008; 105:260-5.

25. Davies KJA, Quintanilha TA, Brooks GA, Packer L. Free radical and tissue demage produced by exercise. Biochem Biophys Res Comm 1982; 107: 1198-205.

26. Ji LL. Oxidative stres during exercise: Implication of antioxidant nutriens. Free Radical Biol Med 1995; 18(6): 1079-86.

27. Häkkinen $K$, Pakarinen $A$. Acute hormonal responses to two different fatiguing heavy-resistance protocols in male athletes.J Appl Physiol. 1993;74):882-7.

28. Cappola AR, Xue QL, Ferruci L, Guralnik JM, Volpato S, Fried LP. Insulin-like growth factor-I and interleukin-6 contribute synergistically to diability and mortality in older women. J Clin Endocrinol Metab. 2003; 88: 2019-25.

29. Schwarz AJ, Brasel JA, Hintz RL, Mohan S, Cooper DM. Acute Effect of Brief Low-and High-Intensity Exercise on Circulating Insulin-like Growth Factor (IGF) I, II and IGF-Binding Protein 3 and its Proteolysis in Young Healthy Men. J Clin Endocrinol Metab 1996 Oct; 81: 3492-7. 